\title{
Notes on Beyond Scenography
}

\author{
Rachel Hann ${ }^{1}$ \\ Northumbria University, Newcastle, United Kingdom \\ E-mail: dr.rachelhann@gmail.com
}

\section{Abstract}

This article document the lecture 'Scenographic Futures', presented as part of the session PQ TALKS, at PQ 2019, a position statements called 'Changing the Question' is presented to reflect if rather than asking what is scenography, now the question is what does scenography do? How scenography affects, channels, and orientate experiences of stage, place, and world.

Keywords

PQ 2019. PQ Talks. Scenography. Scenographic.
Este artigo documenta a palestra 'Scenographic Futures', apresentada como parte da sessão PQ TALKS, na PQ 2019, uma declaração de posição chamada 'Changing the Question' é apresentada para refletir se, em vez de perguntar o que é cenografia, agora a pergunta é o que a cenografia faz? Como a cenografia afeta, canaliza e orienta experiências de palco, lugar e mundo.

Palavras-chave

Cenografia. Cenográfica. PQ Talks. PQ 2019. 
In 2019 I published my first book called Beyond Scenography ${ }^{2}$. I wrote the material over five years, but it really started after my experience of PQ 2011. My ten days in Prague were mostly spent working in a converted church as part of a Spatial Lab organized by Dorita Hannah. Our aim was to argue the future of theatre architecture. Twenty-one of us from all over the world were gathered to share, debate and propose new ideas. We were unsuccessful. There were significant differences in how terms like 'scenography' were approached, but also how the stagecrafts associated with this term were practiced differently in different countries. A lot of time was spent discussing our differences provoked by the English usages of terms in other languages. Based on that experience, I wanted to write a book that embraced this idea of difference. An idea that suggests the way scenography is practiced and ways in which scenography is articulated are connected. Particularly in relation to the continental European languages, each have a slightly different spelling for scenography and none of them have the ' $y$ ' on the end (as with the English). In this way, I wanted to recognize that the English language appropriation was not the universal scenography. That was a starting point for Beyond Scenography.

As an academic, I regularly send articles away for peer review and without a doubt I always get the same line of feedback. "This is marvellously rigorous, but way too ambitious". I have often thought that I need to make a t-shirt which simply states, "too ambitious". The pitch for Beyond Scenography received the same, what is often described, as 'mixed feedback'. It was still commissioned, for which I pay credit to Talia Rodgers (then at Routledge, but now at Digital Theatre) for believing in the project. I started with a series of initial questions

1 Rachel Hann is a cultural scenographer who researches the material cultures of performance design, climate crisis, and trans* performance. Since April 2020, Rachel has been Senior Lecturer in Performance and Design at Northumbria University, Newcastle.

2 HANN, Rachel. Beyond Scenography. New York: Routledge, 2019. that looked to recognize the ambition of the project, along with the idea of difference. This amounted to pushing ideas and the conceptual frames of scenography in ways that exceeded some of the orthodoxies of stage design. This focused on six key aims:

1. To embrace the different understandings and practices of scenography;

2. To resist claiming the English as the definitive usage;

3. To embrace scenography as being equally concerned with sound and costume, as well as set and lighting;

4. To imagine how we might talk about scenography beyond a vision-centric position;

5. To reflect on how set designers had been the dominant voice for scenography and how the conceptual frame would shift if considered from other members of the production team / disciplinary standpoints;

6. To fully embrace the contributions that theory can offer the future of scenographic practice.

Based on these aims, I wrote a book for someone just like me who's equally seduced by theory. I believe that theory is thrilling. A 'big idea' can literally change lives, economies, and futures. Nevertheless, I also realize that theory can be highly technical. To aid this, I also have a YouTube channel (HANN, 2020) based on the book. The book is intended for an audience who, like me, didn't leave the University Library for the best part of 15 years. The YouTube series has the same name as the book and looks to articulate some of those ideas that informed the project for a generalist audience. I'm not sure how successful it is in achieving that aim, but it mixes the academic lecture with comedy. In preparation for PQ2019, I edited an episode that was split into nine position statements under the title of 'Scenographic Futures'. The first of these was 'Changing the Question'. Rather than asking what is scenography, now the question is what does scenography do? How scenography affects, channels, and orientate experiences of stage, 
place, and world. This for me is crucial in terms of recognizing where we go in the future theoretically, but also embracing where we had come from. The idea of difference was a central part of that argument.

The basic premise of my own theoretical arguments took, as the starting point, that if something can be choreography and choreographic, performance and performative, theatre and theatricality, dramaturgy and dramaturgical, film and filmic, then something can also be scenography and scenographic. I was interested in considering what happens if something is scenographic, but is not necessarily scenography. An example of this might be a Christmas tree. One reading of this might be that it is a highly scenographic object, but it has not necessarily been created by stage scenographers. This approach positions 'scenography' as something that is occurs as part of an 'aesthetic performance'. Things or events that have similar place orientating qualities, but occur beyond this frame, would be deemed 'scenographic'. Assuming this reading as having a degree of validity, I realized early on that I would need to resist the idea of writing, anywhere in the book, the idea of 'the scenographic' as definitive. I made this decision for two reasons; 1) in using the definitive it becomes monolithic, it becomes essentialist. I wanted to explore the possibilities of a scenographic approach, but I also wanted to avoid defining it in a reductive and ungenerous way. Remember one of my aims was to embrace the different approaches to scenography across linguistic and cultural borders; 2) my own experience of scenography had always been about the combination of costume design, lighting design, sound design and set design. I saw the intersection of these practices as the hallmark of scenography. Scenography was already always plural. It was never singular. I then started researching the histories of 'performative' as an idea. I came across J. L. Austin's presentation at the University of Gothenburg in 1959, which was titled 'Performatives'. I thought if Austin (1962) can talk about performatives, then I can talk about scenographics. I'll pop an 's' on the end, and this revolves my problem of using the scenographic as definitive. After this, I discovered that Darwin Reid Payne had already briefly proposed a similar spelling as part of his 1994 book called Computer Scenographics (PAYNE, 1994). Building off Reid Payne's short paragraph on defining the term, I approached scenographics as a central element to articulating, defending, and proposing new disciplinary avenues for the study of scenography.

This was how the idea of scenographics came to feature in the book. This actually happened quite late on, yet it allowed me talk about multiple stagecrafts and traits coming together. What I was looking to achieve through the concept of scenographics was to articulate the accumulative effect of scenography as produced by a family of perspectives, techniques and practices coming together. This approach also had the secondary aim of offering a conceptual bridge that brings other colleagues who work in theatre and performance studies into the fold of scenography. Whereas previously those who focus on acting or directing may have spoken about staging or set design, they rarely used the term 'scenography' and when they did often ignoring any literature on the subject. Essentially, for those who study plays and even performance theory, there was a perception that scenography was not for them. I wanted to afford a renewed discussion that invited these colleagues into the debate and sought to move beyond the idea the scenography as being for designers only.

To achieve a conceptual bridging and welcoming of other parties, I decided to be bold and embrace a concept that was disliked or ignored by both parties: that of 'worlding'. This is distinct from 'the world', which is definitive. Ideas of worlding embrace that the thing that might be described as 'the world' as always in process. This approach builds directly from ideas of new materialism, which embrace the notions indeterminacy, ecological thinking, assemblage theory, and non-binary thinking. For instance, Donna Haraway's (2016) proposal that being with is a radical act that works against histories of philosophy that demarcate humans as beyond or outside of 'nature'. Haraway's approach rejects the strict on- 
tological binaries of subject and object, human and world, subjective and objective. The flat ontologies of new materialism afford an understanding of humans as being part of a wider assemblage of things that have power over us, as we have power over them. Yet, the human is not overtly privileged within that matrix. Instead, it allows a theoretical framework from which to speculate renewed approaches to human-world relations, which embrace the idea that there is no 'the world' - there is only worlding as an ongoing process. Change is the fixed parameter.

Based on these new materialist ideas, I decided to re-examine the notion of 'the scenic' and its relationship to the 'picturesque'. In particular, I argue that the aesthetic of the picturesque is an aesthetic of ontological distance. As typified by a landscape painting, the subject (human) human observes the object (world) from a distance. As an example of binary thinking, this strict ontology of subject-object situates humans as a separate entity that observe landscape from a critical distance. Humans are not with landscape in this aesthetics model. In new materialism, humans are always part of worlding assemblages. Humans are never outside of world as a process. A good example of this in practice is the use of areas designed to view landscape or a 'scenic view', often at a roadside or in a public park. The picturesque way of approaching this aesthetic task is to look upon world, but they themselves are removed from world. In this instance, world is imagined as something that can be consumed as a resource for human pleasure. To critique this approach, I instead embraced the idea of 'withness' as being central to scenographics. This approach is similar to Adolphe Appia in 1921 stating that the theatre of the future will be the difference between watching a young girl running across a field, and running hand in hand with her. While you could interpret this quite literally as immersive theatre, in terms of scenography even when sitting in an auditorium humans are always connected with the architecture, with our seats, with the lighting, with the sound, with the audience, with the performers, with the set, with the politics of the outside. I argue that withness is central to all scenographic events, whether gardening or even in cosplay, and that this withness is not an exclusive property of immersive theatre. My proposal on the withness of scenographics seeks to exemplify another way of approaching the aesthetics of scenes beyond binary thinking. At this point I wish to reflect further on the idea of worlding. Kathleen Stewart is an anthropologist working in Texas and she's written a lot about the idea of the world and multiplicities the world.

Here, compositional theory takes the form of a sharply impassive attunement to the ways in which an assemblage of elements comes to hang together as a thing that has qualities, sensory aesthetics and lines of force and how such things come into sense already composed and generative and pulling matter and mind into a making: a worlding. (STEWART, 2014, p. 119).

I am really fascinated by the ways in which scenographics can intervene and irritate structures of world and, in doing so, remind us that world was always already in process. That humanity is part of world, and world is not for humanity. A practical example I use in the book is that of a restaurant in Guildford in the United Kingdom, where I lived at the time. It's a trendy Thai restaurant that has tried extremely hard to recreate a feeling of a Bangkok street market, but it's in the middle-class town of Guildford. The building is a long thin unit with no windows. I loved this restaurant. I talk in my book about how highly seductive the interior design was and how all the separates crafts and senses of cooking (smell), design (spatial), textures (haptics), and sounds all worked together to promote a certain feeling of atmosphere or place. I took my father to this space and he said "Rachel, I know you're so interested in all these sorts of things, but you know that dust. Is that scenographic too?". I nodded and said, "Yes, I think so! It's all part of the restaurant's atmospheric qualities. The details matter". In this context, the Thai restaurant acted to orientate a feeling of Bangkok through scenographic techniques. Indeed, 
orientation is a key conception within the book. I adopt Sara Ahmed's dual approach to orientation. Drawn from her book Queer Phenomenology (AHMED, 2006), orientation is both the case of being placed in terms of near and far, as well as how your body is situated in those contexts. Whether you are scared or happy, familiar or strange, she talks about the example of being at a Border Patrol in the United Kingdom, where because she does not have a white body, she is looked upon differently due to the social orientations' others read from her body. While starting with heteronormativity as a dominant orientation, Ahmed moves on to proposes conceptual queer orientations that extends to how we encounter objects from a similar matrix of difference and familiarity, alienation and making strange. This is partly why I never state that scenographics create worlds. Insomuch that scenographics reveal the queer orientations of world that may otherwise be invisible. Instead, I talk about how scenographics score orders of world by highlighting, irritating, othering how worlds are conceptualized as affective atmospheres. Scenographics are produced by the intersection of world narratives (what belongs) and materialities (what materializes). Worlding orientations are, therefore, equally concerned with matters of imagination as they are with the design of objects. In this description is the nub of scenographics - that scenographics allow us to perform world differently.

Based on the notion of queer orientations, I argued that scenographics are always interventional. As an example of what I mean by intervention I turn to an example I included within the book that occurred in Northern Ireland in 2013 as part of the G8 summit. As a group of nations who define themselves as rich, the leaders of these countries would stay in a golf course resort that was approximately 20mins drive from the conference centre. The motorcades of Obama and Putin would have come roaring through small places like Fivemiletown. Driving potentially at high speeds and with blacked-out windows, the local council leaders of the area realized that they wouId be travelled past shops that had all closed down during the recession and never reopened. For mat- ters of context, North Ireland had been economically forgotten by the rest of the UK since 2008 and had not recovered from the economic cash. The people had been left to go through a series of hardships with little support from the UK government. In more recent years, Brexit has offered an interesting new context where the Northern Irish border re-entered the UK cultural imagination as a problem. Whereas in the Northern Irish imagination the border since the good Friday agreement had been a point of freedom.

With regards the 2013 G8 summit, the local council saw an opportunity for international investment. To help their chances they commissioned a graphics company to design trompe l'oeil posters, which were pasted on the full-length windows of the closed shops. This made it look like this is Fivemiletown and other small places were thriving sites of capitalism and commerce. There were posters that turned empty shops into a butcher's, a travel agent, a stationary store, and a café. When driving past at speed, you might be seduced into thinking that Northern Ireland is a prosperous place and may be keep it in mind as a place to invest in the future. While possibly designed with good intentions as the town council was trying to perform a sense of success, in practice the posters acted timely as reminders that Northern Ireland is anything other. In trying to disguise the problem, the scenographics of the posters highlighted the problem in a way that reveals something deep about the politics of the UK.

In conclusion, my aim for Beyond Scenography was to offer a theory of scenography. Now that I am starting plans for my next book, I also realize that it offered the starting point for how scenographics affords a lens on how worlds feelings are produced through crafted place orientations. The idea of scenographic worlding opens the door to a broader discussion on how world narratives are also 'scenographic' in some way. Whether ideas of the 'first world' or 'third world', 'the West' or 'the South', these world narratives are reinforced through a perspective of world that often is communicated through means of scenographics. This might be a map, a story, a 
TV show, or how our language frames other locations, peoples, and events. If these cultural activities are in some way crafting a feeling of place, I argue that they are also, at least partly, scenographic. This follows the idea that scenographics are crafted place orientations and, while explicitly so in theatre, act to other how materialities are ordered in terms of world.

A good example is creative writing. While not spatially based as a practice, literature scholars and creative writers have long between aware of how their stories build worlds through a crafted spatial imaginary that 'feels real'. What is particularly interesting from a theoretical point of view is that these worlds operate in a similar manner to our own 'world'. They afford a sense of another place, which you yourself have not physically been to. Yet you can imagine your own spatial relationship to its peoples, places, and things. This acts in the same logic to the stories we are told about other nations and how they are friendly, hostile or lesser. In that manner, the scenographics of creative writing can be said to amount to the way in which worlds narratives reinforce the politics of world. The scenes of world are then communicated through a range of activities that, often unintentionally, establish a vision of the future that is singular and unchanging. Scenographics offers a perspective on the communication of these narratives that is inclusive of the themed restaurant as well as the graphics of our national news programmes. They all work to afford a sense of world.

The imagined worlds creative fiction are, as with our 'real' world narratives, not exhausted by speculation. For instance, in the Star Trek universe you can take the TV shows and films as canon for the official rules of the Star Trek 'world'. But you can then write your own fanfiction that others, complicates, or imagines another contexts in which these same characters are performing in that same creative universe. Crucially this speculative activity doesn't exhaust the possibilities of that universe. There is an infinite amount of fanfiction that can be written without exhausting the narrative of that universe. The same is true for our own world. We can imagine multiplici- ties that allow us to live differently and how we can be with world differently. These interventions do not exhaust our sense of world. Rather they allow us to realize that world narratives are crafted and that our sense of world is produced by these narratives.

In an era of climate crisis and with the COVID-19 pandemic, we are aware more than ever that change is possible. This is particularly important if we accept that our worldviews and future visions of the future are based on deep narratives that are reinforced again and again in our shared global cultures. I propose that scenographics affords a methodology for revisiting these world narratives and speculating new 'scenes' or worlds that allow us to imagine differently.

In summary, here is the manifesto that featured within Beyond Scenography and offers a working roadmap to the power of scenographics in speculating new world imaginaries:

\begin{abstract}
Scenographics irritate the disciplined orders of world

A scenography of orientation is a scenography of feeling

Skenographia has many legacies

Scenography is not set; scenography happens

Scenography has exceeded the scenographer

There are no stages without scenographics While all scenography is scenographic, not all that is scenographic is scenography Whereas slow architecture pertains to monumentality, fast architecture is scenographic Scenographics score acts of worlding. (HANN, 2019).
\end{abstract}

References

AHMED, Sara. Queer Phenomenology: orientations, objects, others. Durham, NC and London: Duke University Press, 2006.

APPIA, Adolphe. L'oeuvre d'Art Vivant. Genève \& Paris: Edition Atar, 1921.

AUSTIN, John Langshaw. How to do Things with Words. Oxford: Oxford University Press, 1962. 
HANN, Rachel. Beyond Scenography. New York: Routledge, 2019.

E4: Scenographic Futures. Rachel Hann's

Youtube channel. Available in: < https://www.youtube. com/watch?v=uCfgS4VeMzl >. 08 jun. 2020.

HARAWAY, Donna. Staying with the Trouble; Making Kin in the Chthulucene. Durham: Duke University Press, 2016.

PAYNE, Darwin Reid. Computer Scenographics. 1st ed. Carbondale and Edwardsville: Southern Illinois University Press, 1994.

STEWART, Kathleen. Tactile Composition. In: HARVEY, Penny; CASELLA, Eleanor Conlin; EVANS, Gillian; KNOX, Hannah; MCLEAN, Christine; SILVA, Elizabeth B.; THOBURN, Nicholas; WOODWARD, Kath. (Eds.). Objects and Materials. New York and London: Routledge, pp 775-810, 2014.

Recebido: 02/03/2020

Aprovado: $20 / 06 / 2020$

This is an open-access article distributed under the terms of the Creative Commons Attribution License 4.0 International. Available at: <http://creative commons.org/licenses/by/4.0>. 